\title{
EFFECT OF NaCl AND SUPPLEMENTAL CALCIUM ON GROWTH PARAMETERS AND NITRATE REDUCTASE ACTIVITY IN MAIZE
}

\author{
ElŻbieta SacaŁa, AgnieszKa Biegun, Anna DemcZuk, Edward GrzyŚ \\ Department of Plant Nutrition, Agricultural University \\ Grunwaldzka 53, 50-357 Wrocław, Poland \\ e-mail: sacala@ozi.ar.wroc.pl
}

(Received: October 8, 2004. Accepted: January 10, 2005)

\begin{abstract}
In this study, investigated were the effects of $\mathrm{NaCl}\left(60 \mathrm{mmol} \cdot \mathrm{dm}^{-3}\right)$ and $\mathrm{NaCl}$ supplemented with different salts $\left(5 \mathrm{mmol} \cdot \mathrm{dm}^{-3} \mathrm{CaCl}_{2}, \mathrm{CaSO}_{4}, \mathrm{CaCO}_{3}, \mathrm{KCl}\right)$, on growth of two maize varieties (Cyrkon and Limko). After 7 days of cultivation in nutrient solution the growth response to salinity of both maize varieties was similar. $\mathrm{NaCl}$ led to a dramatic decrease in growth of plants (approx. 50\% reduction in fresh and dry weight of root, and $70 \%$ reduction in fresh weight of shoot). Addition of extra $\mathrm{Ca}^{2+}$ or $\mathrm{K}^{+}$to nutrient solution containing $\mathrm{NaCl}$ did not definitely improve the growth parameters of maize. However, among the tested salts, $\mathrm{CaCl}_{2}$ had a beneficial visual effect on maize seedlings. In other cases the plants showed noticeable symptoms of salt damage. In long term exposure to salinity (two weeks) growth of Cyrkon was more inhibited than Limko. Comparison of growth responses in short-term exposure to salinity ( 7 days) with long-term (14 days) showed that in Cyrkon variety the negative effects of $\mathrm{NaCl}$ were intensified and addition of $\mathrm{CaCl}_{2}$ to salinized solution had not positive effects on growth. On the contrary, in Limko variety, there was a significant improvement in growth (especially in root dry weight). This fact indicates that during longer exposure to salinity Limko was able to adapt to those conditions.

Salinity caused a significant decrease in leaf nitrate reductase activity $(60 \%$ and $30 \%$ reduction respectively in Limko and Cyrkon). Addition of $\mathrm{CaCl}_{2}$ to salinized nutrient solution resulted in greater enzyme inhibition in Cyrkon (50\% decline in relation to plants grown under sole $\mathrm{NaCl}$ ), and 30\% increase in Limko. Inhibition of nitrate reductase activity did not cause a decrease in concentration of soluble protein in maize leaves.
\end{abstract}

KEY WORDS: salinity, $\mathrm{NaCl}$, calcium, potassium, nitrate reductase, maize.

\section{INTRODUCTION}

Excessive soil salinity is one of the important factors that limit plant growth and productivity. Under saline condition plants are subjected to both osmotic stress (reduction in water availability) and excessive amount of salt $\left(\mathrm{Na}^{+}\right.$and $\mathrm{Cl}^{-}$toxicity) (Greenway and Munns 1980; Munns 1993, 2002). When exposed to salinity for a short time, growth of plant is limited predominantly by the osmotic effect of salts in soil solution. Salt specific effects occur mainly in older parts of plants after several days at salinity (Neumann 1997; Munns 2002). To overcome osmotic stress same plants use $\mathrm{Na}^{+}$and/or $\mathrm{Cl}^{-}$for osmotic adjustment (Greenway and Munns 1980; Leidi and Saiz 1997). Such ions are energetically efficient osmolytes, but they can have serious effects on plant metabolism. High intracellular concentration of $\mathrm{Na}^{+}$or $\mathrm{Cl}^{-}$may be toxic and can impair the functioning of key cytosolic enzymes (Greenway and Munns 1980). Many researches indicate that the application of supplemental dose of $\mathrm{Ca}^{2+}$ may significantly ameliorate stress symptoms (Cramer et al. 1990; Rengel 1992;
Elphick et al. 2001). Physiological effects of supplemental $\mathrm{Ca}^{2+}$ include, among the others, maintenance of structural integrity of the plasma membrane, prevention of salt-induced decline in cell elongation, improved $\mathrm{K}^{+}$status of the cell and reduced $\mathrm{Na}^{+}$accumulation in plants (Rengel 1992; Shabala 2000). Some scientists have suggested that application of extra $\mathrm{K}^{+}$can also reduce deleterious effects of salinity (Helal and Mengel 1979) and plant tolerance towards salt stress correlates with $\mathrm{K}^{+}$content in plant tissues (Zhu et al. 1998).

In our previous study (Sacała et al. 2002), we have shown that both growth of maize seedlings and nitrate reductase are sensitive to mild salinity. In this study, we concentrated on the possibilities of improvement in maize growth by external addition of $\mathrm{Ca}^{2+}$ and $\mathrm{K}^{+}$. In the first experiment we compared the effects of different calcium salts $\left(\mathrm{CaCl}_{2}, \mathrm{CaSO}_{4}, \mathrm{CaCO}_{3}\right)$ and $\mathrm{KCl}$ on growth parameters of two maize varieties grown under $\mathrm{NaCl}$ stress. When it occurred that only $\mathrm{CaCl}_{2}$ had a beneficial effect on maize growth under salt conditions (plants were smaller than control, but remained healthy without any signs of salt injury), 
in subsequent experiments we used that salt. We also examined the combined action of $\mathrm{NaCl}$ and $\mathrm{CaCl}_{2}$ on nitrate reductase activity and soluble protein content in maize leaves. Additionally, we compared maize growth in two different periods (7- and 14-day old plants).

\section{MATERIALS AND METHODS}

Maize seedlings (Zea mays L. varieties Limko and Cyrkon; seeds were obtained from "Nasiona Kobierzyc" Company) were grown in beakers each filled as follows: modified Knop solution (control), Knop solution with the addition of $60 \mathrm{mmol} \cdot \mathrm{dm}^{-3} \mathrm{NaCl}$, Knop solution with the addition of both $60 \mathrm{mmol} \cdot \mathrm{dm}^{-3} \mathrm{NaCl}$ and $5 \mathrm{mmol} \cdot \mathrm{dm}^{-3}$ supplemental salts one of the following $\mathrm{CaCl}_{2}, \mathrm{CaSO}_{4}, \mathrm{CaCO}_{3}$ and $\mathrm{KCl}$. The culture conditions involved: $16 \mathrm{~h}$ photoperiod $\left(220 \div 240 \mu \mathrm{mol} \cdot \mathrm{m}^{-2} \cdot \mathrm{s}^{-1}\right)$ at $26 / 20^{\circ} \mathrm{C}$ day/night temperature, $65-70 \%$ relative humidity. After 7 days of cultivation plant growth parameters were determined (shoot and root length, fresh and dry weight). Additionally, parameters of plants growth were measured after 14 days of cultivation in Knop solution or in nutrient solution supplemented by $\mathrm{NaCl}$ or $\mathrm{NaCl}$ plus $5 \mathrm{mmol} \cdot \mathrm{dm}^{-3} \mathrm{CaCl}_{2}$ In the second experiment, activity of nitrate reductase and soluble protein content in leaves of 7-days-old seedlings were measured. Extraction and assay of enzyme were performed according to Hageman and Flesher procedure (1960). Plant samples (the first and the second leaf) were homogenized in $50 \mathrm{mmol} \cdot \mathrm{dm}^{-3}$ Tris- $\mathrm{HCl}$ buffer $\mathrm{pH} 7.5$ with addition of $5 \mathrm{mmol} \cdot \mathrm{dm}^{-3}$ cysteine and $2.5 \mathrm{mmol} \cdot \mathrm{dm}^{-3} \mathrm{Na}_{2}$ EDTA. After centrifugation (15 minutes at $20000 \times \mathrm{g}, 4^{\circ} \mathrm{C}$ ) enzyme activity and soluble protein were determined in supernatant. Concentration of nitrite formed was measured colorimetrically by adding $1 \%$ sulfanilamid in $100 \mathrm{mmol} \cdot \mathrm{dm}^{-3} \mathrm{HCl}$ and $0.02 \% \mathrm{~N}$-naphtylethylenediamine (Hucklesby et al. 1972). Protein concentration was determined by Bradford method (1976) with bovine serum albumin (BSA) as the standard.

All experiments were repeated at least six times and all results are presented as means of six separate experiments. The results were subjected to one-factor and two-factors analysis of variance with the least significant test between means (LSD, $\mathrm{p}=0.05$ ).

\section{RESULTS}

After 7 days of cultivation control plants of both varieties had a similar fresh and dry weight, considerably important differences occurred only in the case of root length

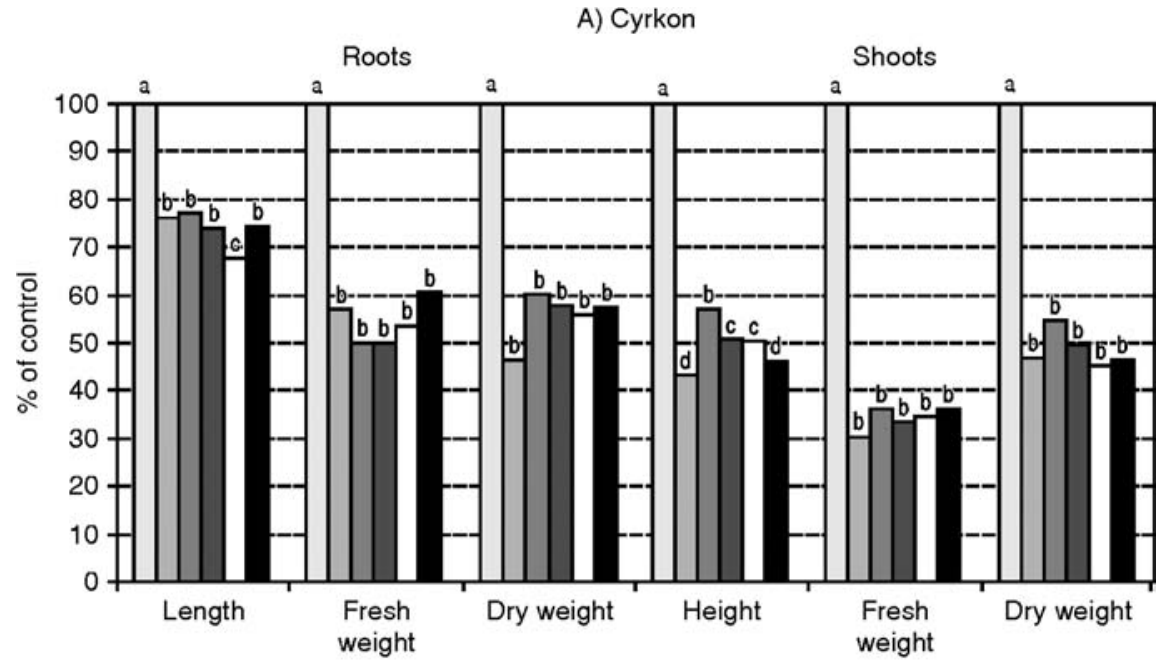

B) Limko

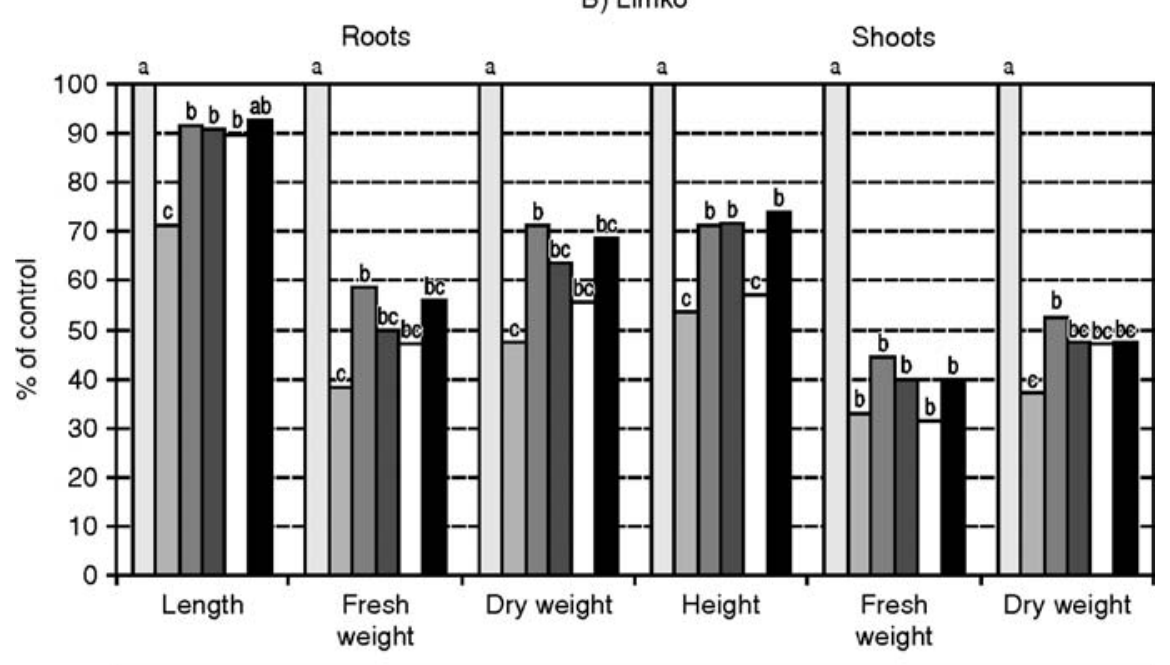

$\square$ control $\square \mathrm{NaCl} \square \mathrm{NaCl}+\mathrm{CaCl}_{2} \quad \square \mathrm{NaCl}+\mathrm{CaSO}_{4} \quad \square \mathrm{NaCl}+\mathrm{CaCO}_{3} \quad \mathbf{a a C l}+\mathrm{KCl}$
Fig. 1. The influence of $\mathrm{NaCl}\left(60 \mathrm{mmol} \mathrm{dm}^{-3}\right)$ and $\mathrm{NaCl}$ plus $5 \mathrm{mmol} \mathrm{dm}{ }^{-3} \mathrm{CaCl}_{2}, \mathrm{CaSO}_{4}$, $\mathrm{CaCO}_{3}$ and $\mathrm{KCl}$ on growth parameters of roots and shoots of Cyrkon (A) and Limko (B) varietes.

Values marked with the same letter do not signicantly $(5 \%)$. 
and shoot height. Cyrkon variety had a bigger size than Limko (data not shown). Two maize varieties responded similarly to salt stress (Fig. 1). Salt treatment (60 $\left.\mathrm{mmol} \cdot \mathrm{dm}^{-3} \mathrm{NaCl}\right)$ led to a dramatic decrease in growth of plants. Moreover, shoot growth was more reduced than root growth. $\mathrm{NaCl}$ caused approximately a $50 \%$ reduction in fresh and dry weight of roots, whereas fresh matter production of shoot decline to $30 \%$ of the control. Addition of extra $\mathrm{Ca}^{2+}$ or $\mathrm{K}^{+}$to nutrient solution containing $\mathrm{NaCl}$ had a not definitely protective effect on growth of seedlings. Negative effects of sole $\mathrm{NaCl}$ and $\mathrm{NaCl}$ supplemented with $\mathrm{CaCl}_{2}, \mathrm{CaSO}_{4}, \mathrm{CaCO}_{3}$ or $\mathrm{KCl}$ on growth of the Cyrkon variety were very similar. In the case of Limko variety the detrimental effect of $\mathrm{NaCl}$ was partially compensated by salts applied. This positive response was notably visible in Limko roots in the presence of $\mathrm{CaCl}_{2}$. There was a $50 \%$ recovery of growth in comparison with the sole $\mathrm{NaCl}$ treatment. It is worth noticing that plants of both varieties grown in solution with $\mathrm{NaCl}$ plus $\mathrm{CaCl}_{2}$ looked healthy and had no visible symptoms of salt injury. In other cases tips of leaves were getting dry.

After 14 days (long-term experiments) of growth in nutrient solution Cyrkon and Limko showed statistically significant differences in growth parameters (Table 1). Control plants of the Cyrkon variety were considerably larger than Limko, but growth parameters of salinized seedlings of both the varieties were similar. Therefore, inhibition of plant growth caused by $\mathrm{NaCl}$ was greater in case of the Cyrkon variety than Limko. Reduction in shoot dry weight was more significant in 14-day old than in 7-day old seedlings of the Cyrkon variety. Therefore, exposure of Cyrkon seedlings to salinity for 14 days resulted in intensifying the detrimental effect of salt. On the contrary, in case of the Limko variety, there was a significant improvement in growth parameters (especially in root dry weight) when compared with 7-day old plants. Addition of $\mathrm{CaCl}_{2}$ to salinized solution did not significantly improve the growth parameters of both varieties.

Nitrate reductase activity in leaves of control plants was markedly higher in Cyrkon than in Limko. Salinity caused a significant decrease in nitrate reductase activity in leaves of both the varieties (Table 2), moreover this decrease was more pronounced in Limko (approx. 60\% reduction) than in Cyrkon (approx. 30\% reduction). Addition of $\mathrm{CaCl}_{2}$ to the salinized nutrient solution resulted in a greater reduction in activity of nitrate reductase in Cyrkon leaves (over $50 \%$ decline in relation to plants grown under sole $\mathrm{NaCl}$ ). Response of Limko variety was opposite, there was a significant increase in nitrate reductase activity (30\% increase compared with $\mathrm{NaCl}$ treatment). Soluble protein concentration in leaves of both varieties was relatively stable under all treatments applied (Table 2).

\section{DISCUSSION}

It is known that $\mathrm{NaCl}$ present in rooting medium interacts with plant nutrients and may cause nutritional disruption, particularly deficiency of calcium and potassium (Rengel 1992; Albercio and Cramer 1993; Sacała et al. 2002). Therefore, addition of extra $\mathrm{Ca}^{2+}$ or $\mathrm{K}^{+}$to saline medium can ameliorate salt stress. Numerous reports indicate that increased concentration of $\mathrm{Ca}^{2+}$ or $\mathrm{K}^{+}$in salinized nutrient solution reduces the deleterious effects of salinity (Helal and Mengel 1979; Cramer et al. 1990; Watad et al. 1991; Rengel 1992; Elphick et al. 2001). However, some reports state that addition of extra $\mathrm{Ca}^{2+}$ to salinized nutrient solution has no ameliorative effect on plants (Ehret et al.

TABLE 1. The influence of $60 \mathrm{mmol} \cdot \mathrm{dm}^{-3} \mathrm{NaCl}$ and $\mathrm{NaCl}$ plus $5 \mathrm{mmol} \cdot \mathrm{dm}^{-3} \mathrm{CaCl}_{2}$ on dry matter accumulation in 7- and 14-day old maize seedlings of two varieties (Cyrkon and Limko). Values in brackets refer to the per cent of control.

Means in the same row marked with the same letter do not differ significantly (5\%).

\begin{tabular}{|c|c|c|c|c|c|c|}
\hline \multicolumn{7}{|c|}{ Dry weight $\left[\mathrm{mg} \cdot\right.$ plant $\left.^{-1}\right]$} \\
\hline & \multicolumn{3}{|c|}{ Cyrkon } & \multicolumn{3}{|c|}{ Limko } \\
\hline & Control & $\mathrm{NaCl}$ & $\mathrm{NaCl}+\mathrm{CaCl}_{2}$ & Control & $\mathrm{NaCl}$ & $\mathrm{NaCl}+\mathrm{CaCl}_{2}$ \\
\hline \multicolumn{7}{|c|}{ 7-day old plant } \\
\hline Roots & $\begin{array}{c}13.65 a \\
(100 \%)\end{array}$ & $\begin{array}{l}6.33 c \\
(46 \%)\end{array}$ & $\begin{array}{l}8.20 b c \\
(60 \%)\end{array}$ & $\begin{array}{c}13.43 \mathrm{a} \\
(100 \%)\end{array}$ & $\begin{array}{l}6.38 c \\
(48 \%)\end{array}$ & $\begin{array}{l}9.58 \mathrm{~b} \\
(71 \%)\end{array}$ \\
\hline $\mathrm{LSD}_{\text {II factors }}$ & & & 2.41 & & & \\
\hline Shoots & $\begin{array}{c}49.04 a \\
(100 \%)\end{array}$ & $\begin{array}{c}22.95 b c \\
(47 \%)\end{array}$ & $\begin{array}{c}26.77 \mathrm{~b} \\
(55 \%)\end{array}$ & $\begin{array}{c}54.05 \mathrm{a} \\
(100 \%)\end{array}$ & $\begin{array}{l}20.04 \mathrm{c} \\
(37 \%)\end{array}$ & $\begin{array}{c}28.28 b \\
(52 \%)\end{array}$ \\
\hline $\mathrm{LSD}_{\mathrm{II} \text { factors }}$ & & & 6.68 & & & \\
\hline \multicolumn{7}{|c|}{ 14-day old plant } \\
\hline Roots & $\begin{array}{c}23.52 \mathrm{a} \\
(100 \%)\end{array}$ & $\begin{array}{l}13.15 \mathrm{c} \\
(56 \%)\end{array}$ & $\begin{array}{l}10.74 d \\
(46 \%)\end{array}$ & $\begin{array}{c}16.96 b \\
(100 \%)\end{array}$ & $\begin{array}{c}11.94 \mathrm{~cd} \\
(70 \%)\end{array}$ & $\begin{array}{c}11.66 \mathrm{~cd} \\
(69 \%)\end{array}$ \\
\hline $\mathrm{LSD}_{\text {II factors }}$ & & & 2.08 & & & \\
\hline Shoots & $\begin{array}{c}97.35 \mathrm{a} \\
(100 \%)\end{array}$ & $\begin{array}{l}31.02 \mathrm{~d} \\
(32 \%)\end{array}$ & $\begin{array}{l}41.14 c \\
(42 \%)\end{array}$ & $\begin{array}{c}77.02 b \\
(100 \%)\end{array}$ & $\begin{array}{c}37.21 \mathrm{~cd} \\
(48 \%)\end{array}$ & $\begin{array}{l}43.65 \mathrm{c} \\
(57 \%)\end{array}$ \\
\hline $\mathrm{LSD}_{\mathrm{II} \text { factors }}$ & & & 8.62 & & & \\
\hline
\end{tabular}


TABLE 2. The influence of $60 \mathrm{mmol} \cdot \mathrm{dm}^{-3} \mathrm{NaCl}$ and $\mathrm{NaCl}$ plus $5 \mathrm{mmol} \cdot \mathrm{dm}^{-3} \mathrm{CaCl}_{2}$ on nitrate reductase (NR) activity and concentration of soluble protein in leaves of 7-day old maize seedlings of two varieties (Cyrkon and Limko). Values marked with the same letter do not differ significantly (5\%).

\begin{tabular}{|c|c|c|c|c|c|c|}
\hline & \multicolumn{3}{|c|}{$\mathrm{NR}$ activity $\left[\mathrm{nmol}\left(\mathrm{NO}_{2}^{-}\right) \cdot \mathrm{g}^{-1} \mathrm{FW} \cdot \mathrm{h}^{-1}\right]$} & \multicolumn{3}{|c|}{ Protein concentration $\left[\mathrm{mg} \cdot \mathrm{g}^{-1} \mathrm{FW}\right]$} \\
\hline & Control & $\mathrm{NaCl}$ & $\mathrm{NaCl}+\mathrm{CaCl}_{2}$ & Control & $\mathrm{NaCl}$ & $\mathrm{NaCl}+\mathrm{CaCl}_{2}$ \\
\hline Cyrkon & $852.0 \mathrm{a}$ & $606.0 \mathrm{~b}$ & $325.0 \mathrm{c}$ & $9.9 \mathrm{a}$ & $10.6 \mathrm{a}$ & $10.9 \mathrm{a}$ \\
\hline $\mathrm{LSD}_{0.05}$ & & 61.1 & & & 1.7 & \\
\hline Limko & $654.0 \mathrm{a}$ & $266.0 \mathrm{c}$ & $346.0 \mathrm{~b}$ & $11.2 \mathrm{a}$ & $12.5 \mathrm{a}$ & $10.9 \mathrm{a}$ \\
\hline $\mathrm{LSD}_{0.05}$ & & 59.3 & & & 2.5 & \\
\hline
\end{tabular}

1990; Leidi et al. 1991; Caines and Shennan 1999; Sohan et al. 1999). Moreover, according to literature, plants response to supplemental $\mathrm{Ca}^{2+}$ or $\mathrm{K}^{+}$is dependent on the kind of salt used and its concentration (Islam et al. 1987; Caines and Shennan 1999). In our study we investigated four different salts $\left(\mathrm{CaCl}_{2}, \mathrm{CaSO}_{4}, \mathrm{CaCO}_{3}, \mathrm{KC}\right)$ and we have established that all the tested salts had a similar effect on growth of 7-day old plants under saline conditions. The application of extra $\mathrm{Ca}^{2+}$ or $\mathrm{K}^{+}$did not definitively protect the plants from negative effects of salt stress. However, $\mathrm{CaCl}_{2}$ had a noticeable positive effect on seedlings. Plants showed a reduced growth, but looked healthy, without any symptoms of wilting. It is worth noting that the positive effect of supplemental salts on plant growth was more pronounced in the Limko variety than in Cyrkon. Literature data prove that salt sensitive cultivars/species are more responsive to supplemental $\mathrm{Ca}^{2+}$ than salt tolerant ones (Ehret et al. 1990; Albercio and Cramer 1993; Elphick et al. 2001). Accordingly, Limko seems to be more sensitive to salinity than Cyrkon.

The comparison of maize growth after 7 and 14 days of salt treatment indicates that there were differences between Limko and Cyrkon. After 14 days of exposure to salinity, growth of the Cyrkon variety was more reduced than that of Limko. Moreover, the inhibition of dry mass production was higher than in 7-day old seedlings. The response of Limko variety was quite different; the inhibition of plant growth after 14 days of salt treatment was lower than that after 7 days. These data suggest that within prolonged time of salinity the seedlings of Limko are able to adapt to salt conditions. In spite of the assumption mentioned above, this physiological trait of growth response may lead to the conclusion that Limko is more salt tolerant than Cyrkon. Thus, the obtained results do not allow to distinguish definitively which variety is more tolerant to salinity. Various reports indicate that there are varietal differences in growth responses to salinity (Aslam et al. 1993; Cramer et al. 1994; Neumann 1997). However, Munns (2002) reported that during a short time in salinity it is difficult to assess the differences in plants' salt tolerance, since the decrease in growth rate may be the same for species that have quite different reputations for salt tolerance. In our experiment the differences in growth parameters between Cyrkon and Limko varieties appeared after two weeks. Under control conditions Cyrkon seedlings showed a faster growth rate than Limko, but under salt stress this trend did not occur. Salinity can affect plant growth in various ways. In the first phase (in early term of salinity) inhibition of plant growth is due to osmotic stress and later (in long-term exposure) there are additional effects connected with excessive salt accumulation (Munns 1993, 2002). Thus, the observed varietal differences in growth parameters (after 14 days of salt stress) might suggest that Cyrkon and Limko differ in their ability to overcome both osmotic and toxic effects of excessive amount of salts.

In order to establish the effect of salt stress on metabolic status of plants, we have chosen nitrate reductase and protein content (Table 2). Nitrate reductase (NR), which catalyses reduction of nitrate to nitrite, is recognized as the rate-limiting step of the nitrate assimilation pathway (Campbell 1999). Nitrate reductase is responsive to metabolic and physiological status of plants, hence it is used often as an indicator of plant stress (Campbell 1988; Lorenzo et al. 2001). Regarding leaf NR activity, we observed a marked decrease of NR activity under saline conditions, which remains in agreement with our previous investigations (Sacata et al. 2002) and numerous literature data (Gouia et al. 1994; Omarov et al. 1998; Silveira et al. 2001). Plants' response to supplemental $\mathrm{Ca}^{2+}$ was different in the two maize varieties examined. In the case of Cyrkon, a synergistic effect between $\mathrm{NaCl}$ and $\mathrm{CaCl}_{2}$ was observed. The inhibition of $\mathrm{NR}$ activity amounted to $62 \%$, whereas under sole $\mathrm{NaCl}$ it ranged only to $39 \%$. In the case of Limko, there was an increase in NR activity in the presence of both $\mathrm{NaCl}$ and $\mathrm{CaCl}_{2}$ in comparison to plants grown under $\mathrm{NaCl}$ only (30\% increase as compared with $\mathrm{NaCl}$ treatment).

The decrease in NR activity under salt treatments did not cause any significant changes in the level of soluble protein in leaves of both varieties. Abd-El Baki et al. (2000) indicated that in spite of decreased total activity of NR under salt stress, the concentrations of free amino acid and protein in maize leaf tissues were higher than in control plants. Accordingly, the cited authors concluded that salt-dependent decrease in maize growth was not due to impaired nitrate assimilation and that nitrate reduction exceeded the demands. Other researchers (Gilbert et al. 1998) also provided a similar conclusion that under conditions of reduced plant growth the amount of nitrogen is in excess in relation to the demands and therefore plants accumulate nitrogencontaining compounds as sinks for excess nitrogen.

\section{CONCLUSIONS}

The presented experiments showed that mild salinity (60 $\left.\mathrm{mmol} \cdot \mathrm{dm}^{-3} \mathrm{NaCl}\right)$ significantly reduces fresh and dry weight of both maize varieties Cyrkon and Limko, and application of extra $\mathrm{Ca}^{2+}$ or $\mathrm{K}^{+}$does not definitively improve plants growth under salt conditions. The results obtained indicate also that inhibition of nitrate reductase activity do- 
es not decrease the concentration of soluble protein in leaves of both varieties.

\section{LITERATURE CITED}

ABD-EL BAKI G.K., SIEFRITZ F., MAN H.-M., WEINER H., KALDENHOFF R., KAISER W.M. 2000. Nitrate reductase in Zea mays L. under salinity. Plant Cell Environ. 23: 515-521.

ALBERCIO G.J., CRAMER G.R. 1993. Is the salt tolerance of maize related to sodium exclusion? I. Preliminary screening of seven cultivars. J. Plant Nutr. 16: 2289-2303.

ASLAM M., QURESHI R.H., AHMED N. 1993. A rapid screening technique for salt tolerance in rice (Oryza sativa L.). Plant and Soil 150: 99-107.

BRADFORD M.M. 1976. A rapid and sensitive method for the quantification of microgram quantities of protein utilising the principle of protein dye binding. Anal. Biochem. 72: 248-254.

CAINES A.M., SHENNAN C. 1999. Interactive effects of $\mathrm{Ca}^{2+}$ and $\mathrm{NaCl}$ salinity on growth of two tomato genotypes differing in $\mathrm{Ca}^{2+}$ use efficiency. Plant Physiol. Biochem. 37: 569-576.

CAMPBELL W.H. 1988. Nitrate reductase and its role in nitrate assimilation in plants. Physiol. Plant. 74: 214-219.

CAMPBELL W.H. 1999. Nitrate reductase structure, function and regulation: bridging the gap between biochemistry and physiology. Annu. Rev. Plant Physiol. Plant Mol. Biol. 50: 277-303.

CRAMER G.R., ALBERCIO G.J., SCHMIDT C. 1994. Leaf expansion limits dry matter accumulation of salt stressed maize. Aust. J. Plant Physiol. 21: 663-674.

CRAMER G.R., EPSTEIN E., LÄUCHLI A. 1990. Effects of sodium, potassium and calcium on salt-stressed barley. I. Growth analysis. Physiol. Plant. 80: 83-88.

EHRET D.L., REDMANN R.E., HARVEY B.L., CIPYWNYK A. 1990. Salinity-induced calcium deficiencies in wheat and barley. Plant and Soil 128: 143-151.

ELPHICK C.H., SANDERS D., MAATHUIS F.J.M. 2001. Critical role of divalent cations and $\mathrm{Na}^{+}$efflux in Arabidopsis thaliana salt tolerance. Plant Cell Environ. 24: 733-740.

GREENWAY H., MUNNS R. 1980. Mechanism of salt tolerance in nonhalophytes. Annu. Rev. Plant Physiol. 31: 149-190.

GILBERT G.A., GADUSCH M.V., WILSON C., MADORE M.A. 1998. Amino acids accumulation in sink and source tissues of Coleus blumei Benth. during salinity stress. J. Exp. Bot. 49: 107-114.

GOUIA H., GHORBAL M.H., TOURAINE B. 1994. Effects of $\mathrm{NaCl}$ on flows of $\mathrm{N}$ and mineral ions and on $\mathrm{NO}_{3}{ }^{-}$reduction rate within whole plants of salt-sensitive bean and salt-tolerant cotton. Plant Physiol. 105: 1409-1418.

HAGEMAN R.H., FLESHER D.1960. Nitrate reductase activity in corn seedlings as affected by light and nitrate content of nutrient media. Plant Physiol. 34: 700-708.

HALPERIN S.J., GILROY S., LYNCH J.P. 2003. Sodium chloride reduces growth and cytosolic calcium, but does not affect cytosolic $\mathrm{pH}$, in root hairs of Arabidopsis thaliana L. J. Exp. Bot. 54: 1269-1280.

HELAL H.M., MENGEL K. 1979. Nitrogen metabolism of young barley plants as affected by $\mathrm{NaCl}$ - salinity and potassium. Plant and Soil 51: 457-462.

HUCKLESBY D.P., DALLING M.J., HAGEMAN R.H. 1972. Some properties of two forms nitrate reductase from corn (Zea mays L.) scutellum. Planta 104: 220-233.

ISLAM A.K.M.S., ASHER C.J., EDWARDS D.G. 1987. Response of plants to calcium concentration in flowing solution culture with chloride or sulphate as the counter-ion. Plant and Soil 98: 377-395.

LEIDI E.O., NOGALES R., LIPS S.H. 1991. Effect of salinity on cotton plants grown under nitrate or ammonium nutrition at different calcium levels. Field Crops Res. 26: 35-44.

LEIDI E.O., SAIZ J.F. 1997. Is salinity tolerance related to $\mathrm{Na}$ accumulation in Upland cotton (Gossypium hirsutum) seedlings? Plant and Soil 190: 67-75.

LORENZO H., SIVERIO J.M., CABALLERO M. 2001. Salinity and nitrogen fertilization and nitrogen metabolism in rose plants. J. Agr. Science 137: 77-84.

MUNNS R. 1993. Physiological processes limiting plant growth in saline soils: some dogma and hypotheses. Plant Cell Environ. 16: 15-24.

MUNNS R. 2002. Comparative physiology of salt and water stress. Plant Cell Environ. 25: 239-250.

NEUMANN P. 1997. Salinity resistance and plant growth revisited. Plant Cell Environ. 20: 1193-1198.

OMAROV R.T., SAGI M., LIPS S.H. 1998. Regulation of aldehyde oxidase and nitrate reductase in roots of barley (Hordeum vulgare L.) by nitrogen source and salinity. J. Exp. Bot. 322: 897-902.

RENGEL Z. 1992. The role of calcium in salt toxicity. Plant Cell Environ. 16: 625-632.

SACAŁA E., DEMCZUK A., GRZYŚ E., SOBCZAK A. 2002. The effects of salt stress on growth and biochemical parameters in two maize varieties. Acta Soc. Bot. Pol. 71: 101-107.

SHABALA S. 2000. Ionic and osmotic components of salt stress specifically modulate net ion fluxes from bean leaf mesophyll. Plant Cell Environ. 23: 825-837.

SILVEIRA J.A.G., MELO A.R.B., VIÉGAS R.A., OLIVEIRA J.T.A. 2001. Salinity-induced effects on nitrogen assimilation related to growth in cowpea plants. Environ. Exp. Bot. 46: 171-179.

SOHAN D., JASONI R., ZAJICEK J. 1999. Plant - water relations of $\mathrm{NaCl}$ and calcium-treated sunflower plants. Environ. Exp. Bot. 42: 105-111.

WATAD A.-E.A., REUVENI M., BRESSAN R.A., HASEGAWA P.M. 1991. Enhanced net $\mathrm{K}^{+}$uptake capacity of $\mathrm{NaCl}$-adapted cells. Plant. Physiol. 95: 1265-1269.

ZHU J.-K., LIU J., XIONG L. 1998. Genetic analysis of salt tolerance in Arabidopsis: evidence for a critical role of potassium nutrition. Plant Cell 10: 1181-1192. 